\title{
General Issues of Homonymy in the Persian Language
}

\author{
Mastura N. Akhmedova ${ }^{1} \&$ Almira K. Garayeva ${ }^{1}$ \\ ${ }^{1}$ Kazan (Volga Region) Federal University, Kazan, Russia \\ Correspondence: Mastura N. Akhmedova, Kazan (Volga Region) Federal University, Kremlyovskaya Street 18, \\ Kazan 420008, Russia. E-mail: ahmadova_74@mail.ru
}

$\begin{array}{lr}\text { Received: April 14, } 2015 & \text { Accepted: April 20, } 2015 \quad \text { Online Published: April 27, } 2015 \\ \text { doi:10.5539/jsd.v8n4p126 } & \text { URL: http://dx.doi.org/10.5539/jsd.v8n4p126 }\end{array}$

\begin{abstract}
The importance of the problem under investigation is the following: it indicates important sub-levels and lexical-semantic features of homonyms in the modern Persian language; it observes the material basis of linguistic nature of these phenomena (homonyms), elevating the issue to the level of the fundamental current problems, which are under multidimensional analysis, synthesis, generalization on a scientific level nowadays. Theoretical foundations of the common problems of homonymy in modern Persian as the main aspect of a global lexical study are represented in this paper. It was revealed that the traditional principles of general differentiation of homonyms into three common classes (lexical, morphological and lexical - grammatical) in modern Persian due to its linguistic features is not sufficient. In addition, groups of situational and mixed homonyms were detected. The investigation highlights the examples of homonymy formed by grammatical means (prefixes, suffixes); homonymy of compound words, the cases which have not been traditionally is not represented in the previous lexicological works, as well as their lexical-semantic differentiation and their interaction at the level of literary and dialectal vocabulary. The article proceedings can be are useful for the linguists, the experts of lexicology and language teachers. Also it can be recommended for undergraduates, post graduate students and students of high school with in-depth research training in the field of linguistics.
\end{abstract}

Keywords: Persian language, occurrence of homonyms, lexical-semantic differentiation of homonyms, internal and external homonymy

\section{Introduction}

\subsection{The Importance of the Problem}

The issues of the lexical semantics of the word and ways of its expression in lexicology nowadays attract the attention of many linguists, primarily in connection with the study and analysis of the functioning of homonyms, which do not have common semantic features, that enable to correspond several word units to one general word meaning. The research should be based on the material that reflects the regularities of their origin, development, modification, operation and distribution. Also it should cover such issue as a specific structure of homonyms in language and speech. Lexical homonyms arise due to various reasons, which have their own characteristics. In some cases homonyms have different meanings and they are united as polysemantic words. These processes are implemented variously in different dictionaries. Sometimes the difficulty of accurate distinguishing both polycemy and homonymy makes it necessary to study, analyze and summarize the lexical-semantic features of homonyms in modern Persian language. A historical analysis and more definite view of homonyms may clarify the problem and identify the origin of many words, the meanings of which haven't been completely identified yet.

\subsection{Explore Importance of the Problem}

The main aspect of such investigations must be determined by a common problem of homonymy as a global problem at the lexical level. The most consistent, complete and an elaborate classification of homonyms of the modern Persian language and the most exhaustive information about them determines study of the material basis of the linguistic nature of these phenomena (homonyms), that elevates the issue to the level of the fundamental current problems, which are under multidimensional analysis, synthesis, generalization on scientific level today.

In the modern Iranian linguistics semantics and classification of homonyms haven't been thoroughly investigated. Just the works of the Russian scientists such as V.A.Kochergina (1970), L.S.Peysikova (1975), Yu.A.Rubinchik (1983), iranian researchers B.Hodzhi (1987) and A.Birdzhandi (2002), as well as modern Tajik researchers 
A.Muminova (1975) M.Allamurodova (1991) Sh.Kabirova (1992) A.M.Bayzoeva (1992) and Z.Abdulazizova (2008), devoted to issues of lexicology of the Persian and the Tajik languages, give us the general information. The Tajik linguist Sh.Kabirov (1992) touches upon the issues of homonymy or ratio of units in some of the works. His attention is focused on the trends of various transformations and semantic range of the words; semantic ties and relations of the units; he defines a nature of their origins and sources of formation of such categories of words (Kabirov 1992).

Among the researches of Iranian scientists concerning the homonymy the work of Bahrom Khodzhi (1987) should be highlighted. His dictionary «Kāmeltarin farhange loghāte motašābeh» ("A complete dictionary of similar units") covers about 30 thousand homonymous lexical units and groups of the word signs of the Persian language (Khodzha Bahrom,1987). There is another researcher Ahmad Birdzhandi, who wrote a work titled «Shive-ye āmuzeše emlā-ye zabāne fărsi va negāreš» (Methods of teaching spelling and writing of the Persian language ) (Birdzhandi, 2002).

These papers are devoted to the issues of the Persian spelling, including some comments upon the complexities of the "mutashobeh" units that are revealed during the learning process. Unfortunately, these investigators haven't touched upon the issue related to the homonym or homonymy, or groups of homonymous words and their origin.

In general, the problem of homonymy in the modern Iranian linguistics has not found its scientific and theoretical evaluation and interpretation.

Taking into account the above mentioned circumstances the main aim of our research is to establish important sublevels and lexical-semantic features of homonyms in the modern Persian language, that are still not represented as an urgent problem of fundamental researches, which are supposed to be thoroughly scrutinized.

\subsection{Practical Significance}

The practical significance of the work is that proceedings can help students to use correctly homonyms, homophones, homographs in speech, as well as to recognize them in an accurate Persian calligraphy.

\subsection{Status of a Problem}

At the same time, in connection with the laws of the Persian and the Tajik languages, apart from the opposite views on the phenomenon of homonymy, there are some other problematic issues awaiting to be observed and evaluated. One of them is the dependence of homonymy on the type of writing and the specifics of the alphabet. The Persian writing system differs from the Tajiik so interpretation of homonymy may cause contradictory opinion that appears during characteristics of incomplete homonyms.

Another important aspect of the issue, which still remains unexplored in the Persian language, is a homonymy of the compound words. It is carried out by peculiar ways; hence it requires a special analysis.

Particularly, a random coincidence or borrowing words from the other languages aren't the way homonymy of compound words occur. They mostly occur as a result of semantic seclusion or usage of the word as a term.

\subsection{Hypothesis of the Research}

Taking into account the linguistic features of the modern Persian language and analysis of the examples we can conclude that the differentiation of homonyms into three common classes (lexical, morphological and lexical grammatical) is insufficient for defining their specific features. In fact this classification gives only a general idea about the linguistic reality of homonyms that has been reflected in the nature of these homonymous groups and their common meaning. Obviously, detailed elaboration of the conceptual and semantic volume of homonym is required even in terms of a single meaning. The matter is that not only can every group of them can be represented as a more fractional and smaller subgroup, but also the most numerous groups of homonyms, their nominations are connected by various characteristics.

\section{Materials and Methods}

\subsection{The Objectives of the Research}

Making the analysis of homonyms in the Persian language and their characteristics, in accordance with the research source, we can indicate the groups of the mixed and situational homonyms, although this statement hasn't been scientifically accepted in the language, so it requires a detailed investigation and generalization. We can classify homonyms and their linguistic peculiarities into the following groups:

1. Lexical homonyms. By establishing the ways of forming lexicographic model of lexical homonyms in the Persian language, which have already become traditional, and are essentially based on the linguistic reality of 
their method of notation, we got the opportunity to determine their subclasses. Their interpretation contains an indication of the way they were generated, which can be divided into the following types:

1) Random sound matching of some words in the language. For example, the word «tir» [shooting], has in the Persian the following homonymous definitions: tir I - gun bullet; tir II- long stick, pole; gaff; staff; tir III - name of the fourth month of the calendar of the solar year of Hidzhra in Iran.

2) Homonyms resulting from dissociation of semantics of the previous polysemantic words. This phenomenon covers the interrelation of polysemy and homonymy. For example, a unit daste [däste] has the following meanings: I 1) a group, company, the ensemble; 2) the brigade; 3) team; 4) gang; 5) platoon, detachment; 6) herd, flock; 7) bunch, beam; 8) class, rank, category; 9) the range, set. daste [däste] II 1) leather (knife, ax, etc.); 2) armrest (chair); 3) technical - lever - daste [däste] III outdated word - twelve o'clock (after sunset or sunrise); afternoon; midnight (Rubinchik, 1983).

3) Process when native words combine with loanwords. Such examples are numerous in Persian. They form the following groups: a) Persian and Arabic words: šahr [shähr] I city; II plural - šohur month (lunar); b) The Persian and Russian-European words: pors [pors] I the basis of the present tense of the verb "porsidan" [porsidän] ask; pors [pors] II portion (food). At the same time the Russian loanword becomes a homograph for this homonym pres [pres] pressure; the press (muscle); bār [bar] I 1) load, burden; 2) fruit (about fruits) bār [bar] II times (once,twice etc), the first time. bār [bar] III reception, the audience (at the head of the state). bār [bar] IV the basis of the present tense of the verb "bāridan" go (for rain, etc.). bār [bar] V - trivet, stand for the boiler. bār [bar] VI - bar, restaurant. bār [bar] VII - Lord God! 2) obsolete - Mister.

2. Morphological homonyms (or grammatical homonyms) are a class of word units belonging to different parts of speech. V.A.Kochergina holds views that grammatical or morphological homonyms are homonyms arising from coincidental consonance of words of different parts of speech in various forms" (Kochergina, 1970). In modern Persian and Tajik languages verbs of the present tense in conjunction with other units of language often acquire homonymous features. This phenomenon of homonymy can be seen in the following example: ruy [rui] I face, cheek; ruy [rui] II the basis of the present tense of the verb rastan (grow); ruy [Rui] III copper; tin (Rubinchik 1983). This group of homonyms may also include words bāz, guy, juy and others.

3. Lexical - grammatical homonyms are a class of homonyms, which absorbed the features of the first two groups - homonyms arisen as a result of the conversion of the words and their transfer from one part of speech to another without structural changes. For example, dido I view (noun, participle); dida II eyes (noun) (Normatov, 1995). The phenomenon of transition of different words related to other parts of speech into the category of nouns, which is called in lexicology as "substantivation", is considered as one of the productive and very common prerequisites for the origin of grammatical homonyms. Characterization of these homonymous paradigms has become a good start for detailed analysis and class of mixed homonyms.

4. Mixed homonyms. In our opinion, this class of homonyms is the special type which requires to focus on the peculiarities of their semantics and to recognize a certain "proximity" of their definitions in relation to the different realities. Consideration of their pecularities is directed to three interrelated areas of study of their hypostasis: 1) to the functional aspect; 2) to the aspect of the lexical system; 3) to the aspect of the lexicographical practice. In the Persian and Tadzhik languages there are some cases when one and the same word having several meanings joins to a group of ambiguous words, in certain semantics - to a group of full homonyms, in some meanings - to the one homonymous group and due to other lexical potentialities - to other homonymous categories. Variations of this class of vocabulary are accounted by lexicographic rules and provide an opportunity for them to be considered as a group of mixed homonyms. So, M.Muin notes four homonymous semantics of the unit "on" (Muin, 2008):

ān (pahlavi) zamire ešāre berāye dur, moqābele in.

ān (esm) az mostalahāte sufeyāne ast va ān now i hosn-o zibāyi ast ke qābele dark ammā towsifnāpazir ast.

ān (arabi) vaqt, hengām, zamāne andak. jam` ānāt// dar yek ān - dar yek lahze, dar yek dam.

ān 1- pasvand.... (Muin, 2008).

In fact, the above analyzed examples assure that the local performance of the homonymous units - "on" refers specifically to the described realities. And this becomes particularly evident in their interpretation in the contextual conditions of different levels, because only the defining functions and grammatical semantics of the sign (on) is indicated by the 9 cases of the usage of the suffix "-on".

Another category of homonyms is also noteworthy, the usage of which is predetermined by the context. 
5. Situational and contextual homonyms. This class of homonyms was considered by us in the combination of their lingvospecific features. To them we referred some homonyms which arise only in the context by reducing of composition or using verbs with different bundles: kān (ore, one that - contraction of "ke en"), mādari (mother, dear (adj.); motherhood related to the mother (noun); you are a mother (nominal predicate) or mardi courage (noun); you are a man (nominal predicate), a man (indefinite noun). Consonance and the interaction of lexical homonyms are not related to the rules of phonetics and grammatical structure. They appeared in the historical development of the language. Each homonym, which is considered as two or more specific words, has its own history, which is reflected in the explanatory or etymological dictionaries.

In the range of lexical space of language sometimes there are cases when one particular unit as a result of the impact of historical facts or changes in the social structure goes out the horizons of its usage and acquires another meaning. The specified attribute based on specific historical or social factors is reflected in the content of homonymous units. Thus, some of the units in definite periods of the history of the language retain their ancient image, however, in other circumstances, these units in terms of semantic shades are a subject to certain modifications. These units were used in the past in one sense, and now they have acquired different semantics. Here, the definitions of these units take into account the specificity of designated realities, taking into account the reflection of new functional pointers in the content. This type of homonyms can be conditionally characterized as historical one. Among many examples it should be pointed at the specificity of masdar časbidan "chasbidan" and at the basis of the verb of past tense formed from it časb "chasb" časp "chasp". These are historical homonymous units that in the initial stages of formation of classical literature were used in the sense of "chafta- Kadzhu kileb, hamid "(folded, curve, curved) or alcove, shed.

Concerning the interpretation of the masdar (infinitive) and its other varieties "chaspondan", "chasponidan", "chapsidan", "chafsondan", "chafsonidan" and the basis of its present tense "chasb" and "chasp" A.Dehhudo in "Lugatname" expresses his opinion and refers to the meaning "Kadzh Shudala" (curl, «monharef gaštan» - bend) (Dehhudo, 1967). But this masdar with all its varieties is very far from the original meaning. And in the modern Persian and Tadzhik languages it is used in a completely different meaning as the "stick", "stick together", "stick", etc.

These results help us to believe that it is feasible and practically important for further development of linguistics of semantically altered states (homonyms) as part of theoretical linguistics.

\section{Results}

A comprehensive analysis of homonyms, their status and lexical role as a part of units of the modern Persian language, the interpretation of the semantics and expressions of homonymous units and the processes the formation of homonyms in the Persian language should be classified in two main classes - internal and external processes characterized by the following features:

1. The first group (internal homonymy) comprises homonymous units arisen directly from the internal resources of the source language, which are characterized to the specific preconditions of their origin:

a) Seclusion of semantics of multi-meaning units. Contrast, similarity and connection of multi-meaning and homonymous words represent a linguistic world in its entirety and in all areas of their interaction. This phenomenon is common to all languages.

b) Random matching of two or more lexical units of the language. Sometimes the native language units in the process of historical evolution and development of the language show external compliance while moving away from each other in terms of meaning.

c) Terminologization of common words, when a common word acquires of semantics of new terminology, a process that is accepted in linguistics and interpreted as a phenomenon of "homonymy by signification", although this method is not very productive.

2. The second group (external homonymy) comprises homonymous units arisen from exposure of external factors that caused these changes, especially in the lexical structure of the language.

One of the important prerequisites of homonyms is matching of semantics of loanwords with meaning of native Persian words.

\section{Discussions}

The diversity and pecularities of homonyms, attracting the attention of scientists, remain the most important issue in the study of problems both in terms of lexicology diachrony, and in terms of synchrony. Scientists dealing with the boundaries of lexical ambiguity, detailing of the conceptual and semantic scope of the lexical 
words of discharge, even within the meaning of certain types of homonyms take different positions. A group of scientists consider polysemy and homonymy as two lexical categories independent of each other. Another group of researchers believes that homonyms are also ambiguous words. Researcher A.Muminov (1975) emphasizes that "The interconnectedness of these two lexical categories is explained by the fact that some homonyms due to distancing of one of the meanings of ambiguous words arise from the surrounding of native meanings. Historically, the roots of such homonymy and ambiguous words are the same, but today they express two concepts "(Muminov, 1975). Yu.A.Rubinchik also considers expansion of primary meaning of units as the main cause of homonyms. And he refers to the fact that as a result of expansion of the semantics of the word it gets a new additional meaning (Rubinchik, 1983).

Distinctive features of polysemy and homonymy are defined in the context with considering their purpose and conditions of usage. But the question of how each of these two categories of words of vocabulary is appropriate to refer to such information in relation to their lexicons context is not idle because polysemantic units have their synonyms. The starting position of the analysis is the fact that in case of fixing of two congruent words in a text and replacing one of them with a synonym this word becomes the polysemantic word, in other words homonym. It should be stressed that in some languages some grammatical criteria of homonyms may also exist. (Muminov, 1975).

One of the important issues related to homonymy is the relation of phenomenon of homonymy to differnet parts of speech. According to some of the concepts some lexicologists (M.Muhammadiev (1997), H.Talbakova (1997), N.Dzhuraev (2002)) homonymy is mostly characteristic for nouns. In our view, problem-controversial views of scientists on the dominant character of nouns as homonyms is the most narrow definition because indicators of other parts of speech are also determined by the frequency fixed in a number of examples given by us as definite cases of the process of homonymy of words belonging also to the auxiliary parts of speech.

\section{Conclusion}

Classification issues of homonyms according to phonetic features and grammatical peculiarities in the Persian have also their own characteristics. The existence of a large number of homographs, homophones and omoforms in the modern Persian language is interconnected with the peculiarities of its writing system and the alphabet.

Classifying incomplete homonyms we could disclose the panorama of homonymy of grammatical means (prefixes, suffixes) traditionally not represented in the previous works on the lexicology. It allows us to systematize the lexical richness of the modern Persian language, their lexical-semantic differentiation and their interaction at the level of literary and dialectal vocabulary. The prospects for further research can be outlined which becomes very essential for in-depth lexical and semasiological research.

\section{Recommendations}

The article proceedings can be are useful for the linguists, the experts of lexicology and language teachers. Also it can be recommended for undergraduates, post graduate students and students of high school with in-depth research training in the field of linguistics.

\section{Acknowledgments}

The work is performed according to the Russian Government Program of Competitive Growth of Kazan Federal University.

\section{References}

Abdulazizova, Z. (2008). Lozhnye druz'ya perevodchika. Izvestiya Akademii nauk Respubliki Tadzhikistan. Seriya Gumanitarnyh nauk, 4, 61-73.

Akhmanova, O. S. (1969). Slovar' lingvisticheskih terminov. Izdanie 2-e. Moskva: Sovetskaya `entsiklopediya.

Allamurodova, M. (1991). Omonimy. Problemy yazyka i literatury. Dushanbe: 45-54.

Bayzoev, A. M. (1992). Yazyk «Donishnoma» Abuali Ibn Sino (terminy i slovosochetanij). Dushanbe (na tadzhikskom yazyke).

Birdzhandi, A. (2002). Shive-ye āmuzeše emlā-ye zabāne fārsi va negāreš. Chāpe dowom. Tehran: Entesherate Madrase. (Birdzhandi A. Metody obucheniya orfografii i napisaniya persidskogo yazyka. Izdanie 2-e. Tehran: Izdatelstvo Madrase).

Dehkhoda, A. (1967). Loghatname. Vol. 1-50. Tehran.

Dzuraev, N. A. (2002). Sovremennyj literaturnyj tadzhikskij yazyk. Leksika i frazeologiya (Metodicheskoe posobie dlya studentov-filologov). Hudzhand (na tadzhikskom yazyke). 
Kabirov, Sh. (1992). Slovar' omonimov tadzhikskogo yazyka. Dushanbe: Maorif.

Khodzha, B. (1987). Kāmeltarin farhange loghāte motašābeh. Tehran: Khorshide now. (Khodzha Bahrom, Polnyj slovar' analogichnyh edinits (na persidskom yazyke)).

Kochergina, V. A. (1970). Vvedenie v yazykoznanie (materialy k kursu dlya vostokovedov). Moskva: Izdatel'stvo Moskovskogo universiteta.

Maslov, Y. S. (1987). Vvedenie v yazykoznanie: Uchebnik dlya filologicheskih special'nyh VUZov. 2-e izdanie. Moskva: Vysshaya shkola.

Moin, M. (2008). Farhange farsi-ye Moin (yek jeldi). Chape yazdahom. - Tehran. (Muin M. Slovar' persidskogo yazyka Muina (odnotomnyj)). Izdanie odinnadtsatoe. - Tegeran.

Muhammadiev, M., \& Talbakova, H. (1997). Leksika literaturnogo tadzhikskogo yazyka. Dushanbe.

Muller, V. K. (1990). English-Russian Dictionary. Moskva.

Muminov, A. (1975). Polisemiya i omonimiya. Problemy yazyka i literatury. Chast' 2. - Dushanbe: Izd. Tadzhikskogo Gosudarstvennogo Universiteta: 268-275.

Normatov M. (1995). Vvedenie v yazykoznanie. Dushanbe: Maorif.

Peysikov L. S. (1975). Leksikologiya sovremennogo persidskogo yazyka. Moskva: Izdatel'stvo Moskovskogo universiteta.

Rubinchik U. A. (1983). Persidsko-russkiy slovar': V 2-h tomah. Moskva: Russkiy yazyk.

\section{Copyrights}

Copyright for this article is retained by the author(s), with first publication rights granted to the journal.

This is an open-access article distributed under the terms and conditions of the Creative Commons Attribution license (http://creativecommons.org/licenses/by/3.0/). 